\title{
A Sociological Comparative Study to Vladimir Lenin and Antonio Gramsci's views on the State
}

Mahir A. Aziz - Social Work Department - College of Arts - Salahaddin University. Email:mahir.aziz@hotmail.com

Saleem P. Elias - Sociology Department - College of Arts - Salahaddin University. Email: selim.elias@yahoo.com

\section{Abstract}

This theoretical study tries to illustrate, evaluate and compare Vladimir Lenin and Antonio Gramsci's views on the state. In doing so the study will try to answer this vital question: to what extent Gramsci's ideas were dependent upon those of Lenin and more specifically, to what extent is Gramsci's analysis of the capitalist state ultimately no more powerful than that of Lenin? It should be emphasised that this study has been done according to a comparative methodology of the history of theory applied in the fields of sociology in general and political sociology in particular. Basically, this study has been done according to an explanatory approach applied in both fields of politics and political sociology. This study divided into eight sections. The first section devoted to the introduction. The second section deals with Lenin's view on the revolution, power and the socialist state. The third section explains Gramsci's view on the hegemony of the party and the state. Section four treats Gramsci's view on hegemony and the civil society. Section five, however, is explaining Gramsci's view on the proletariat, the leadership and the passive revolution. Section six will be dealing with Gramsci's view on Western countries and his conception of civil society. Section seven evaluates and reviews both Lenin and Gramsci's theories of the state. The last section presents the conclusion of the study.

Keywords: State, Socialism, Marxism, Party, Capitalism, Communism, Hegemony. 


\section{Introduction}

The history of Marxism is the history of nineteenth-century thinkers and twentiethcentury politicians. It is also the history of twentieth-century men who are at once thinkers and politicians. To put it in its most obvious form: Both Lenin and Gramsci clearly represents the case. Lenin and Gramsci are thinkers of high quality, and both are among the most accomplished politicians of the last hundred years. (Mills, 1962: 451-452). However, in the history of the twentieth-century's Marxism, one can observe that the period from 1917 to the mid-1920s can be characterized as the age of Leninism, from 1924 to early 1950s that of Stalinism, and from the late 1950s to early 1970 s that of Maoism and the 1980 s are likely to usher in what may be called a new phase of "Gramscism.". (Piccone, 1976: 485). The twentieth century communism has made several distinctive contributions to the theory and practice of modern politics. One of the innovations of the Bolsheviks which Lenin adopted and practiced is the theory of power.

Both Vladimir Ilyich Lenin (1870-1924) and Antonio Francesco Gramsci (1891-1937) are amongst the most influential Marxist thinkers in the twentieth century. Lenin established himself as the most influential Marxist thinker after successfully leading the first Socialist Revolution in Russia in October 1917.

In contrast to Lenin, Gramsci was almost unknown outside his country, Italy, until the late 1960's. However, today, nearly 81 years after his death, he is known as one of the outstanding contributors to Marxism along with Lenin, Rosa Luxemburg and Trotsky. Today, politics and sociology students in many Universities throughout the world discuss Gramsci's writings.

This essay will discuss, compare and evaluate both Lenin and Gramsci's theory of the state and examine whether Gramsci's analysis of the capitalist state was more powerful than that of Lenin? 


\section{Lenin's view on the Revolution, Power and the Socialist State}

Against the nineteenth-century liberal democracy view which shows social decisions as a reconciliation of diverse interests through compromise and consensus, power was defined as a monopoly of the means of coercion. Power as Daniel Bell puts it "was thought of almost in terms of physics, its equation being almost literally 'mass times force equals power”. (Bell, 1962: 293).

Lenin's view on the state is considered as his most significant contribution to Marxist theory. Lenin developed his idea regarding the state in his famous book entitled 'State and Revolution' (1917). In his book he defined the state as "a special organization of force: it is an organization of violence for the suppression of some class." (Lenin, Selected Works, vol.2, 1968: 320)

Lenin considered Liberal Democracy as a system which people can only once every few years decide which member of the ruling class rule over them. To him the state was a machine for the repression of one class by another regardless of being in the form of dictatorship or a parliamentary system. Lenin, like his all contemporary Marxists, believed that power is concentrated in the state. Therefore, he saw the capture of power as the main aim of a revolutionary strategy which could provide the necessary condition for the construction of socialism.

To him the appropriate type o state for socialism (or the appropriate form of dictatorship of the proletariat) was the Paris commune type of state; a model, which had been, recommended by Karl Marx himself. He considered the dictatorship of the proletariat as the context of the socialist state and the Paris Commune or the soviets as its form. Lenin maintained that such a state begins to wither after a successful socialist revolution. However, he had no clear idea, how the institutional form of this transition would be when he wrote the 'State and Revolution'. (Burns, 1936: 721726).

A few years later as the head of the new Socialist State, Lenin showed much less optimism for the immediate withering of the state. In a speech in the Seventh Party Congresses, in response to the request of some members of the Communist Party including Bukharin who had demanded an immediate withering of the state, he said; 
"We shall have managed to convene more than two Congresses before the time comes to say: see how our State is withering away. It is too early for that. To proclaim the withering away of the State prematurely would distort the historical perspective." (Lenin, Collected Works, vol.27: 148).

Lenin also changed his mind in respect of the relationship between the party and the state. Lenin's theory of the 'party' was based upon his criticism of the 'economism'. He criticized the advocates of 'economism' who maintained that the economic development in capitalism would gradually conduct the capitalism system to a range of crises ultimately leading to its collapse. Lenin echoed both Marxist theoreticians Georgi Plekhanov (1856-1918) and the Czech-Austrian philosopher, Karl Kautsky's (1854-1938) criticism of 'economism' and argued that it is impossible for the proletariat to gain the (class) consciousness, needed for a successful victory at the national level against bourgeoisie, from its day to day economic struggle. (Polan, 1984: 27)

He maintained that, it is the task of Social Democracy (the party) to take the socialist ideology within the proletariat and led its political struggle in the national level against the bourgeoisie. Before the 1917 revolution Lenin saw the role of the party as the organizer of the proletariat's struggle and never showed a sign to replace the soviets or the proletariat dictatorship with the rule of party. However, in 1919 in a book called 'Left-Wing Communism' An infinite disorder went too far to say that the class relationships being exercised 'under the leadership of the party'. (Lenin, Collected Works vol. 31:48). Later on, in practice the dictatorship of the proletariat was replaced by the dictatorship of the party, when the central Communist Party decided to dissolve the consequent Assembly - which the Bolsheviks had a minority - and began a systematic suppression of the opposition.

Although Lenin was a key figure in the hierarchy of decision making in these years, he was not quite satisfied with bureaucratization of the new state. In the last Party Congress, he attended he said:

"If we take the bureaucratic machine, the gigantic heap, we must ask: who is directing whom? I doubt very much whether it can truthfully be said that the Communist are 
directing that heap. To tell the truth, they are not directing, they are being directed. (Lenin, Collected Works. vol. 33: 288).

Despite a shift away from placing stress upon the significance of the Soviets to emphasize the role of the party, Lenin never rejected his early ideas on the Paris Commune as an appropriate form of Socialist state. He also never considered the dictatorship of the party as a form of the proletariat's dictatorship.

It should be clear that it was Lenin who first used the concept of hegemony systematically (in relation to the leading role of the working class vis-à-vis the peasantry). Lenin, however, gave huge attention to the role of the vanguard party, and theorized two stages of capitalism (competitive and monopoly capitalism), and who recognized the interests in imperialism of Western labor aristocracies. But most important Lenin was the first to focus on the problems of the state and the transition to communism. (Polan, 1984: 39).

\section{Gramsci: The hegemony of the Party and the State}

Gramsci was twenty-six at the beginning of 1917. Alastair Davidson stated: "Between 1919-1922 Gramsci had read most of Lenin's books and he accepted the theory in them especially his theory of the party but did not subscribe to the soviet style of Leninism". (Davidson, 1977: 138). It should be cleared that Gramsci did not directly criticize Lenin's definition of state. Nevertheless, his view regarding the functions of state clearly shows that he was not convinced that the state is simply "an instrument of the ruling class " which is used as a "machine for the repression of one class by another ", as Lenin had defined the state. In one of his writings in the Prison Notes, Gramsci gave a clear account of his view with regard to the relative autonomy of the state form ruling class:

"is true that the state is seen the organ of one particular group, destined to create favorable conditions for the latter's maximum expansion. But the development and expansion of the particular group are conceived of, and presented as being the motor of force of a universal expansion, of a development of all the 'national' energies". (Simon, 1991: 14) 
Gramsci's theory of 'hegemony' is essential in understanding his theory of state. He took the term 'hegemony' from Lenin. With the concept of hegemony, he indicated that the success and survival of any ruling class depends on persuasion as well as coercion. With the concept of hegemony, Gramsci means that in order to seize and maintain power, a class and its representatives need to exercise power over other classes by means of a combination of coercion and persuasion. (Hoare and Smith, 1971: 254) To Gramsci no ruling class could seize and especially maintain power without obtaining other class's consent. The idea of hegemony in this sense is particularly essential to understand the reasons behind the long survival of Capitalism in the advanced Capitalist countries with a parliamentary regime. With regard to the exercise of hegemony in the parliamentary system Gramsci wrote:

The 'normal' exercise of hegemony in the area which has become classical, that of the parliamentary regime, is characterized by the combination of force and consensus which vary in their balance with each other, without force exceeding consensus too much. Thus it tries to achieve that force should appear to be supported by the agreement of the majority, expressed by the so-called organs of public opinionnewspapers and association... Midway between consists and force stands corruption or fraud (which is a characteristic of certain situations in which the exercise of the function of hegemony is difficult, making the use of force to dangerous). (Joll, 1983: 99)

\section{Gramsci: Hegemony and Civil Society}

To Gramsci, ruling classes exercise the political power over other classes not only by means of the state, but also throughout the whole range of institutions and organizations in civil society. Thus power concentrated in the state. Gramsci borrowed the term civil society from Hegel, but gave a new dimension to it. Hegel regarded civil society as the sphere of economic relations. However, Gramsci expanded the meaning of civil society to that part of the superstructure that is not under direct control of the state, such as trade union, schools, churches and family. With regard to the definition and importance of civil society for exercising hegemony by different classes Gramsci wrote: 
"What we can do, for the moment, is to fix two major superstructure 'level': the one that can be called 'civil society', and that of 'political society' or 'the state; These two levels correspond on the one hand to the functions of 'hegemony' which the dominant group exercises throughout society and on the other hand to that of 'direct domination' or command exercise through the state and 'juridical' government". (Hoare and Smith, 1971: 245) and (Simon, 1991: 69).

It is throughout these institutions and organizations which classes engage in political and ideological struggles and each class try to obtain hegemony over others. In civil society not only class struggles, but all the 'popular-democratic' struggles (such as women struggle for equal rights with men or minority groups struggles for political power) is a struggle for obtaining hegemony. To obtain hegemony, each class needs to engage in all areas of struggles, not only in the direct class struggle with rival classes. From Gramsci's point of view, the proletariat should begin exercising power over other classes in all areas of social relations before the seizure of political power. In one of his Prison Notebook he states:

"A social group can, indeed must, already exercise 'leadership before winning governmental power (this is indeed one of the principal conditions of the winning of such power); it subsequently becomes dominant when it exercises power, but even if it holds it firmly in its grasp it must continue to lead as well”. (Joll, 1983: 101)

To do so, Gramsci maintained that the proletariat had to look for the creation of a political coalition with other classes and take an active part in the popular-democratic struggles. The proletariat should organize a counter-hegemony against the bourgeoisie by engaging in all economic, political and ideological struggles in order to gain the contest of other classes. This strategy was called 'war of position' by Gramsci; a strategy which is distinct from the 'war of movement' which aims to seize the governmental power in a sudden movement though revolution as experienced in the Russian Revolution. Gramsci didn't reject the 'war of movement' as a successful strategy, but could not see a chance of access for this strategy in the East European countries. Gramsci especially placed emphasis on necessity of creating a system of alliances with other classes. He stated; 
The proletariat can become the leading and dominant class to the extent that it achieving success in creating a system if alliances which allowed it to mobilize state. (Simon, 1991: 24).

\section{Gramsci: The Proletariat, the Leadership and the Passive Revolution}

To become a hegemonic class Gramsci stressed that the proletariat needs to go beyond considering only other class's interests. There are many sphere of 'national-popular' struggle which the proletariat should have a leading role. The women struggle for equal rights with men; struggles for civil liberties or national liberation are some examples of such struggles which can attract people's attentions from different classes.

Although Gramsci stressed on the proletariat struggle to achieve the leadership in the sphere of production, he maintained that the proletariat leadership this sphere only could be achieved and to be maintained if it were combined with its leadership in a block of social forces in civil society. He called these processes of achieving the leadership in the production sphere and spheres of 'national-popular' as creation of 'historical block'.

To win the 'war of position' Gramsci saw a significant role for the intellectuals to fulfill. He maintained that 'the achievement and maintenance of hegemony is largely a matter of education (Joll, 1983: 101). Such a role, however, could be fulfilled if there was an organic relationship between intellectuals and masses. Without such a strong relationship between leaders and led, there was a danger of rising bureaucracy which was one of Gramsci's major concerns.

Gramsci distinguished the proletariat way of obtaining hegemony over other classes from the way in which the bourgeoisie exercise and re-established its hegemony over other classes. He labeled the way of the bourgeoisie as a 'passive revolution'. He argued that the bourgeoisie's initiative to organize and reproduce its hegemony was an initiative from above and avoided large conscious participation of the masses. From his point of view, the rise of fascism in Italy was an example of 'passive revolution', whereby economic reform implemented from above and by the state. What he suggested as an alternative for the proletariat was an anti-passive revolution 
which, involving a large participation of the masses in all areas and all stages of the war of position.

\section{Gramsci: Western Countries and Civil Society}

Gramsci distinguishes the states of Western Europe from those of the East with reference to a set of institutions that grows up around the coercive core of the state, which Gramsci calls, drawing on Hegel. "Civil Society". In the famous note where Gramsci makes this distinction he writes:

"In the East (Russia) the State was everything, civil society was primordial and gelatinous; in the West there was a proper relationship between State and civil society, and when the State trembled a sturdy structure of civils society was at once revealed. The State was only an out ditch, behind which there stood a powerful system of fortresses and earthworks" (Hoare and Smith, 1971: 238).

Gramsci made it clear that a strategy which aims to capture the governmental power in a single historical moment is not an appropriate strategy for the Western countries with a developed civil society. His view regarding civil society and the way the proletariat should seize and maintain power certainly evolved. However, what was wrong with the revolutionary strategy advocated by Lenin and the third International was not only its failure to propose a viable path for capturing power by Communist parties in the Western countries with an expanded civil society (as Gramsci rightly realized). The most significant flaws in this strategy were; firstly, having seizure of power by the party (and not the promotion of people's class-consciousness) as the main goal of the revolution. Secondly, being ambiguous regarding the role of party in an ideal type of political structure before the October revolution of 1917 and supporting a political structure based on the domination of party (and not Soviets) as the main guarantor of the construction of socialism. In fact, the strategy supported by Lenin and the Third International did not aim to pave the way for 'changing the proletariat from a class within itself to a class for itself as Karl Marx believed; it simply wanted the party to seize and remain in power.

Gramsci's theory of state was not so radical to overcome such flaws in Lenin's theory. In fact, Gramsci did not fully break with the main themes of Lenin's theory which, 
despite all its ambiguities, saw a political system based on the power of the party (and not the Soviets or any other form of masses' self-governing institutions which could provide real opportunity for exercising power by masses) as an ideal type of political structure for socialism. Before the factory councils' defeat Gramsci placed stress on importance of the Italian Factory Council as an appropriate form of a new political structure. He saw these factory councils as an appropriate instrument for educating proletariat, and as an alternative for the bourgeois state. (Simon, 1991:24) In an article which was published in L'Ordine Nuovo (the new order) Gramsci wrote;

"The factory council is the model of the Proletariat State. All the problems inherent in the organization of the proletarian State are inherent in the organization of the council... The council is the most fitting organ of mutual education and development of the new social spirit that the proletariat has succeeded in expressing". (Femia, 1981: 141).

Gramsci considered the factory council as superior institutions with the 'representatives; or public' character that make an active participation of workers an indispensable part of their jobs and their position in society.

However, despite the profound impact of the factory councils' experience on Gramsci thoughts, the defeat of the councils led him to pay more attention to the significance of the party for a successful revolutionary state. Such a shift from the councils to the party has caused a big controversy amongst Marxists whether Gramsci favored the party or councils. Before the defeat of the factory council as Joseph V. Femia puts it, "Gramsci looked at the party to a mere 'agent' a strategic and tactical adviser to the spontaneously burgeoning mass movement". (Femia, 1981: 53) However, by the end of 1920 he was more in line with the Third International doctrine which saw a decisive role for the party in the organizing the proletariat revolution. Gramsci described the party as an instrument for educating and directing the proletariat, a role which he saw for the factory council before their defeat. In fact, the strategy supported by Lenin and the Third International did not aim to pave the way for 'changing the proletariat from a class within itself to a class for itself' as Marx believed; it simply wanted he party to seize and retain power. 


\section{Lenin and Gramsci}

Lenin saw the revolution as the most visible way of capturing government power and as being the ultimate goal of his revolutionary strategy, seeing seizure and retaining power as being the ultimate goal of the revolution and the main guarantor of the construction of socialism after the revolution led Lenin to place more emphasis upon the role of the party against the masses' self-governed institutions such as the Soviet's. Later, he was even convinced that, to keep political power, the restriction on people's democratic rights (including the proletariat's democratic right) and the physical elimination of the opposition, was inevitable.

To Gramsci, however, this way of capturing and preserving the political power was not an appropriate way in the Western European countries with a developed civil society. Therefore, he suggested using the civil society institutions to gain the consent of other classes as a way for seizing and preserving power. However, (in a similar way to Lenin) Gramsci maintained that the seizure of power by the proletariat meant the seizing of power by the party.

If replacing the role of masses' self-governing institutions with the party in Lenin's theory paved the way for the emergence of a totalitarian state, the strategy suggested by Gramsci paved the way of the liberalization for the communist parties and abandoning the radical goals. The Communist parties of Western countries-unlike their counterpart in the ex-socialist countries that saw totalitarianism as the only way to preserve their power- in the practice realized that the playing down of theory radical goal is an indispensable prerequisite to gain the consent of other classes through civil society's institution in the capitalist society and playing in the ground of Liberal Democracy. (Polan, 1984: 78).

Logically, Gramsci did not envisage abandoning the radical goals held by its follower in the Italian Communist party and other European Communist parties as a possible consequence of his theory (as Lenin did not envisage the establishment of a totalitarian system by Stalin).

However, it seems that Gramsci was too naive about the nature of bourgeois civil society's institutions. It is naive to believe that media, education system, churches 
and family can benefit proletariat to exercise power over other classes as they do benefit bourgeoisie to do so. These institutions are not neutral. There is a price for the proletariat in using these institutions. The price is the gradual abandonment of the radical goals of their replacement with goals achievable in the framework of capitalism.

\section{Conclusion}

To sum up, Gramsci's theory of state was deeply influenced by Lenin. Nevertheless, Gramsci developed Lenin's theory of state and made it much more powerful. Gramsci's theory of state is certainly more powerful than that of Lenin and his theory made a foundation for a new political strategy. His new definition of the state helped him to shade light on strengthens and ability of capitalism to reproduce the neces sary conditions for its strong and long survival. His theory of 'hegemony' and 'civil society' drew a theoretical basis for a new strategy, which could direct the proletariat's struggle against capitalism. Gramsci suggested that the proletariat should seize power through gaining the consent of other classes. However, he remained loyal to the main theme of Leninism which considered the seizure and maintaining of power by the party to be the main goal of the revolutionary strategy. If such a flaw led the followers of Lenin and the Third International to create or advocate a totalitarian state. In Gramsci's case, it led its followers to down play the radical goals in order to get closer to power.

\section{References}

A.J Polan, (1984), 'Lenin \& the End of Politics', University of California Press, Berkeley.

Alastair Davidson, (1977), 'Antonio Gramsci: Toward an Intellectual Biography', Merlin Press, London. 
C. Wright Mills, (1962), 'The Marxists', Penguin Books, London.

Daniel Bell, (1962), 'The End of Ideology' revised edition, The Free Press, New York.

Emile Burns, (1936), ‘A Handbook of Marxism', Victor Gollancs Ltd, London.

James Joll, (1983), 'Gramsci', Fontana Paperbacks, Glasgow.

Joseph V. Femia, (1981), 'Gramsci's Political Thought: Hegemony, Consciousness and Revolutionary Process', Clarendon Press, Oxford.

Paul Piccone, (1976), “Gramsci’s Marxism: Beyond Lenin and Togliatti”, Theory and Society, December 1976, Vol:3, issue 4,PP: 485-512).

Quintin Hoare and Geoffrey Nowell Smith, (1971), 'Selections from the Prison Notebooks', Lawrence and Wishart, London.

Roger Simon, (1991). 'Gramsci's Political Thought: An Introduction', Lawrence and Wishart, London.

V. I. Lenin, (1968), ‘Selected Works’, Lawrence, Moscow.

V. I. Lenin, (1972), 'Collected Works', Lawrence, Moscow. 
المخلص

هذه در اسة نظرية, تحاول تقديم ار اء فلاديمير لينين و انطونيو غر امشى وتقييمها, في خصوص الدولة, وبهذا العمل, تحاول الدراسة الاجابة على سؤال حيوي وهو: الى اى حد اعتمدت افكار غرامشي على اراء لينين, وبالاخص

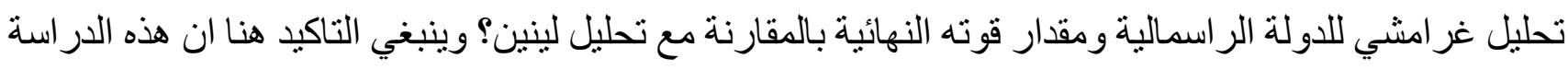

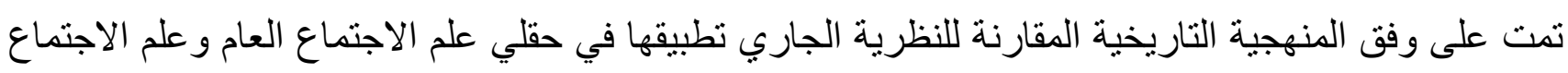
السياسي على وجه اخص. اساسا نم اجر اء هذه الدر اسة بناء على النهج التفسيري في هذين الحقلين. تنقسم الدراسة على ثمانية مباحث, الاول هو مقدمة والثاني يعالج نظرة لينين عن الثورة و السلطة والدولة الاشتر اكية. المبحث الثالث عن نظرة غرامشي حول الهيمنة من طرف الحزب و الدولة. المبحث الرابع هو عن الهيمنة في المجتمع

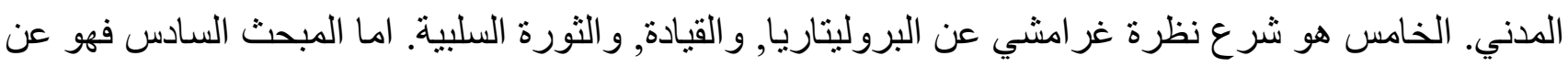
نظرة غر امشي للبلدان الغربية ومفهومة عن المجتمع المدني. اما البحث السابع فهو تثمين لكل من لينين و غر امشي ونظريتها عن الدولة. و الجزء الاخير هو النتائج التي خرج بها ونيع البحث. 


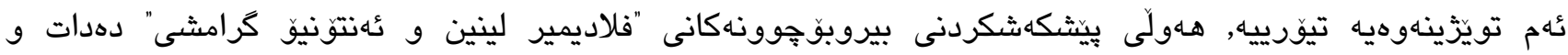

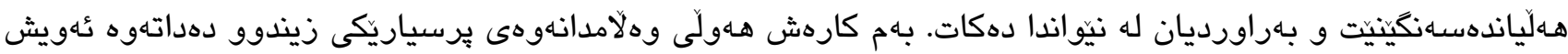
ئهوهيه: تا ع رادهيهك بيرويوّوونهكانى كرامسى يشت به بيربوجوونهكانى لينين دهبهستيت؟ و بهتايبهتيش شيكارى كرامشى بو دهولهتى سهرمايهدارى و برِى هيَّى كوتايى به بهراورد لهكَل لينين؟ و به بيّويستى دهزانين كه جهخت

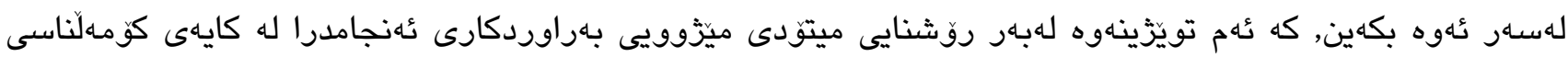
كُشتى و كومهلناسى سياسى بهتايبهتى.

له بنهرهتدا ئهم تويَزينهوهيه يشت دهبهستيت به ميتودى شيكارى لهم دوو بوارهدا:

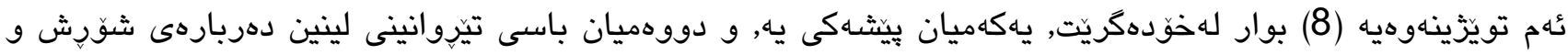
دهسهلات و دهولَّى سوّشياليستى دهكات. بهشى سيّيهم باسى تيّروانينى كرامشى دهربارهى هـزموونى لهلايهن حزب و

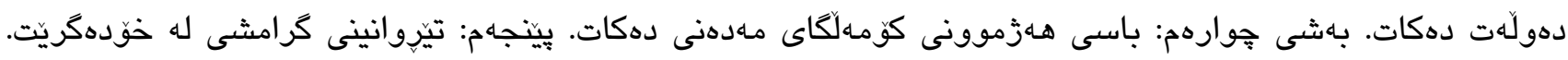

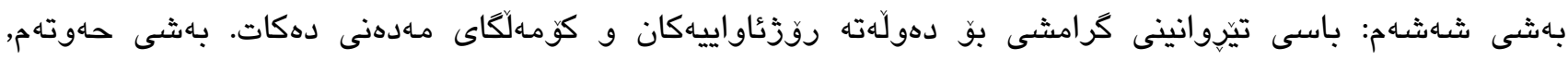

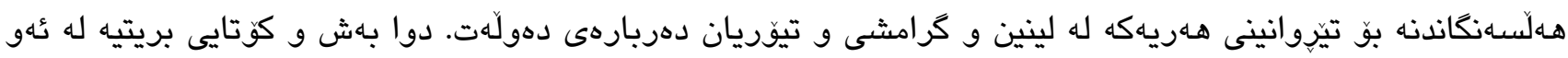
دهرهنجامانهى كه تويّزينهوهكه بهدهستى هيناوه. 